\title{
Aboveground Macroinvertebrate Diversity and Abundance in Sand Sagebrush Prairie Managed With the Use of Pyric Herbivory
}

\author{
Elizabeth D. Doxon, ${ }^{1}$ Craig A. Davis, ${ }^{2}$ Samuel D. Fublendorf, ${ }^{3}$ and Stephen L. Winter ${ }^{4}$ \\ Authors are ${ }^{1}$ Research Associate II, ${ }^{2}$ Associate Professor, ${ }^{3}$ Professor, and ${ }^{4}$ Senior Research Specialist, Department of Natural Resource Ecology and \\ Management, Oklahoma State University, Stillwater, OK 74078, USA.
}

\begin{abstract}
Through pyric herbivory (i.e., fire-induced grazing patterns), native grasslands were historically a spatially heterogeneous environment. It is hypothesized that the mosaic of habitats created by pyric herbivory supports a more diverse invertebrate community compared to modern range management. Patch-burn management, a pyric herbivory technique, is an application of prescribed fire and grazing whereby the timing and location of the burned and grazed patches is varied, creating a diversity of habitat conditions. Although disturbance in sandsage (Artemisia filifolium Torr.) prairie historically included fire and grazing, fire disturbance has been nearly eradicated from this ecosystem in western Oklahoma. We compared patch-burn management to traditional management (i.e., moderate grazing with no fire) in sandsage prairie to evaluate the impact of these two management regimes on aboveground invertebrates. We sampled invertebrates at 44 points in each of $3 \mathrm{mo}$ (May, June, and July) with the use of Dietrick vacuum sampling. Diversity, total abundance, and abundance of seven invertebrate orders (Araneae, Diptera, Hemiptera, Homoptera, Hymenoptera, Lepidoptera, and Orthoptera) were similar between patch-burn and traditional pastures. When examined on a patch level, five invertebrate orders were also similar between their respective time since burn patch and the traditional patches. Araneae and Coleoptera abundance were higher in traditional patches, and Hemiptera abundance was higher in current-year burn patches. Our results suggest a heterogeneity-based management scheme based on pyric herbivory does not negatively impact the overall invertebrate community and may benefit a wider variety of invertebrates by providing areas of varying levels of disturbance. In comparison, homogeneous landscapes such as those created by traditional management may only benefit segments of the invertebrate community that have habitat associations with moderately disturbed or undisturbed areas. Therefore, a disturbance regime involving the interaction of fire and grazing may be valuable for maintaining biodiversity and productivity within sandsage prairie ecosystems.
\end{abstract}

\section{Resumen}

Debido a la hebivoría pírica (v.g. patrones de pastoreo inducidos por el fuego), las praderas naturales fueron históricamente un ambiente espacialmente heterogéneo. Se hipotetiza que el mosaico de hábitats generado por la herbivoría pírica sustenta una comunidad de invertebrados más diversa comparada con aquella generada por las prácticas de manejo de pastizales modernas. El manejo de quemas controladas de parches, una técnica de la herbivoría pírica, es una prescripción del uso del fuego y el pastoreo en la que se varía el momento y ubicación de la quema y el pastoreo de los parches, creando una diversidad de condiciones de hábitat. Si bien el régimen de disturbios de las praderas de Artemisia filifolia Torr. históricamente incluyó fuego y pastoreo, el disturbio del fuego ha sido erradicado casi por completo de este ecosistema del oeste de Oklahoma. Se compararon el manejo del fuego en parches y el manejo tradicional (v.g. pastoreo moderado sin fuego) en una pradera de $A$. filifolia para evaluar el impacto de ambos regímenes de manejo sobre los invertebrados que viven en la superficie del suelo. Se realizo un muestreo de invertebrados en 44 puntos en cada uno de los meses de Mayo, Junio, y Julio utilizando el método de Dietrich. La diversidad, abundancia total, y abundancia de siete órdenes de invertebrados (Araneae, Diptera, Hemiptera, Homoptera, Hymenoptera, Lepidoptera, and Orthoptera) fueron similares entre ambos tratamientos. La evaluación a nivel de parches reveló que cinco órdenes de invertebrados fueron similares en el tiempo desde la quema del parche y los parches tradicionales. La abundancia de Araneae y Coleoptera fue mayor en parches sujetos al tratamiento tradicional mientras que la abundancia de Hemiptera fue mayor en parches quemados en el año en curso. Nuestros resultados sugieren que un manejo que genere heterogeneidad a través de la herbivoria pírica no ejercería efectos negativos globales sobre la comunidad de invertebrados y podría beneficiar a una variedad más amplia de invertebrados mediante la provisión de aéreas con diferentes niveles de disturbio. Comparado con este régimen de manejo, los paisajes homogéneos tales como los que se generan con el manejo tradicional podrían beneficiar solamente a los segmentos de la comunidad de invertebrados asociados con hábitats moderadamente o nada disturbados. Por lo tanto, un régimen de disturbio que incluya la interacción del fuego y el pastoreo podría ser valioso para mantener la biodiversidad y productividad de los ecosistemas de praderas de A. filifolia.

Key Words: grazing, heterogeneity, invertebrates, Oklahoma, patch-burn grazing, prescribed fire, shrublands

Research was funded by Oklahoma State Wildlife Grant Project T-30-P-1 and administered by Oklahoma Cooperative Fish and Wildlife Research Unit.

At the time of the research, Doxon was a research assistant, Dept of Natural Resource Ecology and Management, Oklahoma State University, Stillwater, OK 74078, USA.

Correspondence and current address: Elizabeth Doxon, Center for Native Grasslands Management, 274 Ellington PSB, 2431 Joe Johnson Drive, University of Tennessee, Knoxville, TN 37996-4563,

USA. Email: edoxon@utk.edu

Manuscript received 29 October 2010; manuscript accepted 22 March 2011. 


\section{INTRODUCTION}

Historically, native grasslands in North America were spatially heterogeneous as a result of the intricate relationship between fire and bison (Bison bison) grazing, a disturbance regime now commonly referred to as pyric herbivory (Fuhlendorf et al. 2009). Pyric herbivory research has shown that bison and other herbivores preferentially exploit recently burned areas, whereas the unburned or less recently burned areas of the landscape matrix are grazed at a lower intensity (Fuhlendorf and Engle 2001; Schuler et al. 2006). Within pyric herbivory, a "shifting mosaic" of varying habitat conditions that range from intensively disturbed areas to less disturbed areas is created as locations of burned and grazed areas move across the landscape in space and time (Fuhlendorf and Engle 2001). This historical disturbance regime has been replaced with management practices such as annual burning, season-long grazing, fencing, and strategic placement of minerals and water on rangelands to facilitate the even distribution of grazing animals with the purpose of decreasing the inherent patchiness of grasslands (Holecheck et al. 2004). Consequently, these management practices have resulted in the homogenization of native grasslands (Fuhlendorf and Engle 2001).

Invertebrates in grasslands have roles as pollinators, detritivores, decomposers, insect predators, and parasitoids, and are an important food resource for numerous bird and mammal species (Bock et al. 1992; Marshall 2006). Because of these important roles, invertebrates are often examined as a response to management. Conservationists have been concerned that the typical homogeneity-based approach to rangeland management, particularly annual burning and season-long grazing, may negatively impact native grassland and shrubland invertebrate populations that are vital to many ecosystem processes such as energy flow (Swengel 2001; Debano 2006; Crist 2008).

An alternative to the homogeneity-based approach to rangeland management that attempts to mimic the historic disturbance patterns created by the spatial and temporal interactions of fire and bison grazing (i.e., pyric herbivory) is patch-burn management (Fuhlendorf and Engle 2001, 2004). Patch burning relies on the interaction between prescribed fire and the associated positive and negative feedbacks that influence whether a patch is grazed (Fuhlendorf and Engle 2004). Within a patch-burn framework, grazing intensity varies as the time since burn varies. Work in sandsage mixed-grass prairie suggests that cattle reduce the standing plant biomass of the most recently burned patch by as much as $80 \%$ compared to the unburned areas (Vermeire et al. 2004a). As a result, the vegetation response varies depending on the time since burn. Increased bare ground and forbs occur in recently burned and grazed patches, and higher vegetation structure and litter occur in older burned patches that receive less intense grazing (Fuhlendorf and Engle 2004). Invertebrates cue on changes in vegetation structure such as grasses and forbs, and it is thought that the highly variable landscape created through patch burning would assist in providing the diverse habitat requirements within the invertebrate community.

Although tallgrass prairie ecologists have used pyric herbivory to enhance invertebrate communities (Engle et al. 2008), it is less understood how vegetation structure such as that provided by sandsage prairie influences the invertebrate community. Vermeire et al. (2004b) determined prescribed fire did not influence Orthopteran biomass in western Oklahoma sandsage prairie, but burn plots were small ( $4 \mathrm{ha})$ and the response of other invertebrate orders to the fire-grazing interaction was not examined. As a result, we need a better understand of the fire-grazing interaction and its impact on the invertebrate community in other grassland systems such as sagebrush mixed-grass prairie ecosystems.

The majority of invertebrate management response studies have focused on fire and grazing as distinct and independent disturbances (Reed 1997; Rambo and Faeth 1999; Swengel 2001; Tooker and Hanks 2004; O’Neill et al. 2008). Although it is argued these comparisons are unnatural (i.e., Fuhlendorf et al. 2009), a few trends can be gleaned from these studies. Acrididae and Homoptera densities decline overall under grazing regimes, likely because of the loss of shady, cool microhabitats important for these species (O'Neill et al. 2003; Morris et al. 2005). These studies and others (Jonas et al. 2002; Hartley et al. 2007) suggest an increase in structural heterogeneity may increase diversity and abundance of invertebrates. Unlike grazing, insect populations temporarily decline immediately after a fire, but populations tend to recover quickly (Anderson et al. 1989; Panzer and Schwartz 2000; Panzer 2002). This suggests burned areas within patch-burn pastures may have temporarily low insect populations, but unburned areas within the pasture may serve as refuges, allowing for quick reestablishment of invertebrates in the patch.

Few studies have examined the impacts of pyric herbivory on invertebrate communities. In tallgrass prairie in Kansas, Joern (2004) reported grasshopper (Orthoptera: Acrididae) densities in general were $>2.5 \times$ higher on moderately grazed and burned prairie than ungrazed and burned prairie. Engle et al. (2008) documented invertebrate biomass on an Oklahoma tallgrass prairie managed by patch-burn management was $50 \%$ greater in comparison to traditional, homogeneity-based rangeland management. These studies suggest that pyric herbivory can be used to enhance invertebrate communities in tallgrass prairie, but how invertebrate communities within other grassland ecosystems respond to pyric herbivory has not been studied.

Similar to tallgrass prairie ecosystems, pyric herbivory likely played a major role in shaping sand sagebrush (Artemisia filifolium Torr.) mixed-grass prairie ecosystems in North America (Ramaley 1939; Vermeire et al. 2001; Lauenroth and Burke 2008). Recently, patch-burn management has been suggested as an important conservation tool for maintaining and enhancing sand sagebrush mixed-grass prairie ecosystems (Winter 2010). Consequently, an examination of the influence of pyric herbivory on invertebrates is warranted. Moreover, because shrubs are important structural components of sand sagebrush mixed-grass ecosystems and are not present in tallgrass prairie ecosystems, patch-burn management may have a different impact on the invertebrate community. Additionally, unlike other species of Artemisia, sand sagebrush is a fireadapted species, which makes comparisons to other western sagebrush studies more complicated as the western species tend to be more fire sensitive (Vermeire et al. 2001). Therefore, our objective was to evaluate the response of aboveground macroinvertebrates to patch burning in the sandsage mixed- 
grass prairie of western Oklahoma. Specifically, we compared total invertebrate abundance, invertebrate diversity, and abundance of eight common invertebrate taxa (Araneae [e.g., spiders], Coleoptera [e.g., beetles], Diptera [e.g., flies], Hemiptera [e.g., true bugs], Homoptera [e.g., leafhoppers and spittlebugs], Hymenoptera [e.g., ants and wasps], Lepidoptera [e.g., moths and butterflies], and Orthoptera [e.g., katydids and grasshoppers]) between patch-burn pastures and traditionally managed pastures. Traditional rangeland management in this region is season-long grazing on unburned rangelands. We hypothesize the mosaic of habitat conditions created by rotational prescribed fire and varying grazing intensities will increase overall invertebrate diversity. We also hypothesize the response to fire-grazing interactions by particular invertebrate orders will be influenced by habitat proclivities within the order.

\section{METHODS}

\section{Study Area and Experimental Design}

We conducted this research at Hal and Fern Cooper Wildlife Management Area (hereafter, Cooper WMA) in northwestern Oklahoma (lat $36^{\circ} 34^{\prime} \mathrm{N}$, long $99^{\circ} 34^{\prime} \mathrm{W}$ ) during May-July, 2006-2008. Cooper WMA is 6507 ha in size with topography of rolling upland sandhills (Vermeire et al. 2004a). Actual rainfall during the study (May-July) was $100.5 \mathrm{~mm}$ in 2006, $402.8 \mathrm{~mm}$ in 2007 , and $168.1 \mathrm{~mm}$ in 2008 , compared to a $30-$ yr average of $262 \mathrm{~mm}$ (National Oceanic and Atmospheric Administration 2008). The dominant soil type on Cooper WMA is Pratt loamy fine sands mixed with Tivoli fine sands (Nance et al. 1960). Dominant vegetation includes sand sagebrush and grasses including little bluestem (Schizachyrium scoparium [Michx.] Nash), sand bluestem (Andropogon hallii Hack.), and sand lovegrass (Eragrostis trichodes [Nutt.] Alph. Wood) (Vermeire et al. 2004a).

We conducted this experiment on five pastures. To apply the pyric herbivory to the pastures, we utilized the technique of patch burning. We applied patch burning to three pastures and managed the remaining two pastures according to local management practices (grazing only and no fire; hereafter, traditional). We divided each patch-burn pasture into thirds (each third representing a patch), with each patch ranging in size from 90.6 to $349.2 \mathrm{ha}$, depending on the size of the original pasture. We randomly selected one patch per pasture and burned the selected patch during March. In subsequent years, another patch was randomly chosen for burning, so that by the completion of the study, all patches within the patch-burn pastures had been burned (Fig. 1). All pastures were stocked with cattle at a rate of 6.85 ha/AU from 1 April to 15 September. This stocking rate corresponds to a moderate grazing intensity for this vegetation type (Gillen and Sims 2002). There was no interior fencing within the pastures, which allowed cattle free access to all patches. In the traditional pastures, no large-scale prescribed fire has occurred since the property was purchased by the state of Oklahoma in 1992 (E. Wilson, personal communication, October 2009). However, in 1999-2001, six 4-ha burns had been conducted in the traditional pastures (Vermeire et al. 2004a), but these areas were avoided during our sampling activities (average distance between sampling points and these areas was $511 \mathrm{~m}$ ). We were

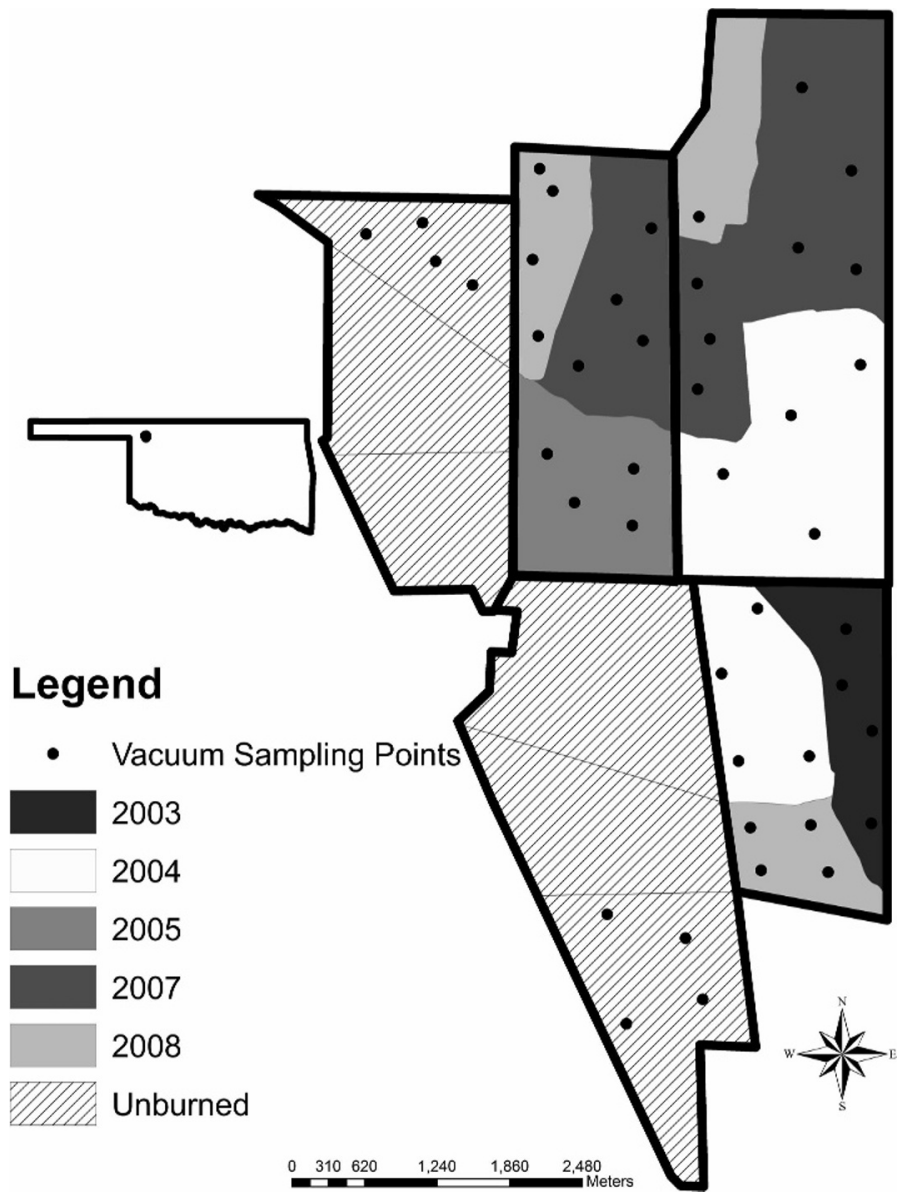

Figure 1. Layout of patch-burn patches (illustrated as shades of gray) and traditional patches (illustrated as cross-hatch) at Cooper Wildlife Management Area near Woodward, Oklahoma, 2006-2008. Pasture boundaries are demarcated by the thick black line.

unable to burn in 2006 because of extremely dry conditions. These patches and patches sampled prior to their burn year are classified in the text and graphs as unburned.

\section{Data Collection and Statistical Analyses}

We vacuum-sampled invertebrates along four 25-m line transects in each patch of each treatment pasture and in one patch in each traditional pasture once in mid-May, mid-June, and mid-July 2006 and 2007 (Dietrick et al. 1960) for a total of 36 transects in the patch-burn pastures and eight transects in the traditional pastures. While walking at a constant pace along transects, we collected invertebrates by holding the intake cone of the vacuum sampler $15 \mathrm{~cm}$ above the ground as invertebrates were collected in a bag attached to the vacuum (Jackson et al. 1987; Burger et al. 1993). In 2008, we were only able to sample in mid-May and mid-June because of equipment failure. After sampling was completed, we stored the collected invertebrates in a freezer until identification. We identified invertebrates to unique categories of morphospecies (Oliver and Beattie 1996; Derraik et al. 2002), but analyzed the data by order. To examine diversity responses in the treatments, we calculated the Shannon-Weiner Diversity Index for morphospecies for each sample (Krebs 1998). 
Table 1. Ecological characteristics of the eight orders examined in western Oklahoma sandsage prairie managed with pyric herbivory.

\begin{tabular}{|c|c|c|c|}
\hline & Families commonly collected ${ }^{1}$ & Feeding strategy & Habitats $^{2}$ \\
\hline Araneae & Araneidae, Oxyopidae, Tetragnathidae & Predaceous & Forbs, grasses, shrubs \\
\hline Coleoptera & Carabidae, Chrysomelidae, Curculionidae, Scarabaeidae & Granivore, mucivore, predaceous, scavenger & Forbs, ground, litter, woody \\
\hline Diptera & Culcidae, Mycetophilidae, Simuliidae, Tabanidae & $\begin{array}{l}\text { Hematophagy, mucivore, nectarivore, } \\
\text { predaceous }\end{array}$ & Forbs, grasses \\
\hline Hemiptera & Lygaeidae, Miridae, Nabidae, Reduviidae & Granivore, mucivore, predaceous & Forbs, ground, litter \\
\hline Homoptera & Caliscelidae, Cercopidae, Cicadellidae, Membracidae & Fungus, mucivore & Grasses, woody \\
\hline Hymenoptera & Braconidae, Formicidae, Halictidae, Ichneumonidae & Herbivory, parasitoid, predaceous & Forbs, grasses, ground \\
\hline Lepidoptera & Hesperiidae, Lycaenidae, Pieridae & Myrmecophily, nectarivores, & Forbs, grasses \\
\hline Orthoptera & Acrididae, Gryllidae, Tettigonidae & Detritivore, herbivore, predaceous & Forbs, grasses, ground, shrubs \\
\hline
\end{tabular}

${ }^{1}$ Refer to Doxon et al. (2011) for more in-depth list of collected families.

${ }^{2}$ Marshall (2006).

We positioned four 100-m transects in each patch for a total of 60 transects and marked each end by a steel post located $10 \mathrm{~m}$ from the end of the transect ( $120 \mathrm{~m}$ between each post). To assess the influence of vegetation on invertebrates, we collected a variety of vegetation data in May and June during each year. At $10-\mathrm{m}$ intervals along each transect, we measured vegetation height and visual obstruction in the four cardinal directions with the use of a visual obstruction pole modified from Robel et al. (1970). We visually estimated percent bare ground, percent cover of litter, and percent cover of vegetation structural groups (live and dead vegetation, grasses, forbs, shrubs, and trees) to the nearest $5 \%$ within a $0.1-\mathrm{m}^{2}$ Daubenmire frame (Daubenmire 1959) that was placed at 10-m intervals along each transect for a total of 10 cover measurements per transect.

To estimate density of sand sagebrush, we counted sagebrush plants within $1010-\mathrm{m}^{2}$ plots, oriented parallel to each transect. We considered sagebrush plants with multiple stems arising from the ground surface to be a single plant if no stem was $>20 \mathrm{~cm}$ from another stem at the ground surface. We also considered stems $>20 \mathrm{~cm}$ from another stem at the ground surface and not known to be connected below the ground surface as separate plants. At each 10-m interval of the transect, we measured the height, width, and length of a randomly selected sagebrush plant to estimate sagebrush volume.

Statistical analyses focused on the invertebrate community with vegetation data used as explanatory variables because comprehensive analysis of vegetation has been thoroughly presented in previous publications (Fuhlendorf and Engle 2004). We used multivariate and univariate analyses to describe the relationship of invertebrates to fire-grazing treatments and vegetation variables. Nonmetric multidimensional scaling (NMDS) based on relative invertebrate abundance data was used to determine compositional patterns in the invertebrate community and identify relationships with vegetation variables in PROGRAM $\mathrm{R}$ (Kruskal 1964; Faith et al. 1987; Minchin 1987; R Development Core Team 2010). Abundance was based on relative abundance of each invertebrate order in each patch. Bray-Curtis distance measure was used in the NMDS analysis. A NMDS scree plot was examined to determine the final number of dimensions. Correlations between axis scores and environmental variables were calculated to identify relationships between invertebrates and vegetation characteristics. Our objectives were not focused on modeling the specific habitat dynamics of each taxa, but rather on identifying simple relationships of invertebrate communities and taxa with the fire-grazing treatments.

We followed the NMDS with univariate statistics to further evaluate the response of individual invertebrate taxa to firegrazing treatments. For each transect, we averaged the three sampling periods. The averaged value was analyzed as a subsample in each patch. To meet the assumptions of normality, we transformed the abundance data for each taxa with the use of square-root transformation (Dowdy et al. 2004) and tested for normality of the variables with SAS PROC UNIVARIATE (SAS Institute 2003). Homogeneity of variances was tested with the use of Bartlett's test for homogeneity of variances in SAS PROC GLM (Zar 2009). After transformation, all variables met the assumption of normality and homoscedasticity. The data presented graphically is backtransformed with standard errors calculated from the original data set. With the use of SAS PROC GLM, we tested effects of time since burn and management type on morphospecies diversity, total invertebrate abundance, and abundances of the eight common taxa by analysis of variance, and subsequently contrasted the least-square means of patch-burn patches and traditional treatment with the use of the pdiff option. We considered contrasts significant at $P<0.05$. For comparison to other studies, we classified time since burn into five categories: current-year burn, 12-24 mo postburn (transitional), $\geq 36$ mo postburn ( $\geq 36$ ), unburned patches (2006 patches and patches prior to their burn treatment) in the treatment pastures and traditional. Table 1 presents an abbreviated list of common invertebrate families collected within each order and their habitat associations.

\section{RESULTS}

Vegetation characteristics varied among patches within patchburned pastures (Table 2). Current-year burn patches contained the shortest vegetation and shrub height and the lowest visual obstruction, shrub density, and shrub volume values. For many of these characteristics, the values were $2-6 \times$ less than in the older and unburned patches in patch-burned pastures and in traditional pastures. Bare ground was about $3 \times$ higher in the current-year burn patches than in traditional pastures. Grass 
Table 2. Vegetation characteristics ( \pm SE) of patch-burn and traditional pastures at Cooper WMA, Oklahoma, USA, 2006-2008. Characteristics were recorded on 36 transects within patch-burn patches and 24 transects within traditional patches. Current patches were year-of-burn patches, transitional patches were burned 12-24 mo previously, and older patches were burned $\geq 36$ mo previously.

\begin{tabular}{|c|c|c|c|c|c|}
\hline & \multicolumn{4}{|c|}{ Patch burn } & \multirow[b]{2}{*}{ Traditional } \\
\hline & Current year & Transitional & Older & Unburned, patch & \\
\hline Vegetation height $(\mathrm{cm})$ & $21.11 \pm 1.18$ & $38.31 \pm 2.10$ & $60.77 \pm 3.94$ & $55.91 \pm 2.50$ & $61.39 \pm 1.94$ \\
\hline Shrub height (cm) & $38.53 \pm 2.54$ & $51.58 \pm 1.82$ & $67.50 \pm 1.49$ & $70.69 \pm 2.08$ & $73.52 \pm 1.19$ \\
\hline $\operatorname{VOR}^{1}(\mathrm{~cm})$ & $2.50 \pm 0.42$ & $6.56 \pm 0.61$ & $14.46 \pm 2.03$ & $13.46 \pm 1.79$ & $16.87 \pm 1.30$ \\
\hline Shrub density & $38.53 \pm 0.45$ & $51.58 \pm 0.32$ & $67.50 \pm 0.25$ & $70.69 \pm 0.44$ & $73.52 \pm 0.17$ \\
\hline Shrub volume $\left(\mathrm{m}^{3}\right)$ & $0.09 \pm 0.01$ & $0.23 \pm 0.02$ & $0.61 \pm 0.05$ & $0.51 \pm 0.04$ & $0.67 \pm 0.04$ \\
\hline$\%$ live vegetation & $44.42 \pm 2.10$ & $48.62 \pm 2.52$ & $58.14 \pm 2.07$ & $47.01 \pm 1.69$ & $50.18 \pm 1.16$ \\
\hline$\%$ dead vegetation & $14.32 \pm 2.08$ & $35.05 \pm 2.10$ & $46.25 \pm 2.35$ & $50.22 \pm 1.87$ & $48.25 \pm 1.34$ \\
\hline$\%$ bare ground & $50.40 \pm 3.03$ & $28.00 \pm 2.27$ & $19.95 \pm 1.91$ & $14.98 \pm 1.82$ & $15.89 \pm 0.99$ \\
\hline$\%$ litter & $21.55 \pm 3.52$ & $27.87 \pm 1.99$ & $37.15 \pm 2.32$ & $39.31 \pm 2.18$ & $43.40 \pm 1.38$ \\
\hline$\%$ grass & $16.97 \pm 1.22$ & $29.35 \pm 1.99$ & $39.40 \pm 1.81$ & $32.86 \pm 1.58$ & $33.75 \pm 1.25$ \\
\hline$\%$ forb & $12.16 \pm 0.55$ & $11.00 \pm 0.88$ & $8.57 \pm 0.49$ & $11.40 \pm 0.68$ & $11.22 \pm 0.32$ \\
\hline$\%$ shrub & $3.95 \pm 0.59$ & $8.12 \pm 0.96$ & $13.58 \pm 1.29$ & $13.63 \pm 1.21$ & $14.50 \pm 0.90$ \\
\hline
\end{tabular}

${ }^{1} \mathrm{VOR}=$ visual obstruction reading

and shrub cover were also reduced by 98 and $267 \%$, respectively, in the current-year burn patches compared to the older and unburned patches in patch-burned pastures and the traditional pastures (Table 2).

Invertebrate community composition varied both with time since fire and within the shifting mosaic treatment. In the NMDS analysis, a solution with four dimensions was achieved. Correlations of the vegetation variable vectors determined that five vectors were significantly correlated with the site scores (Table 3; Fig. 2A). Shrub height and litter, grass, and shrub cover were positively correlated with axis two, indicating a gradient of decreasing grazing pressure. Axis one was positively correlated with bare ground, indicating a gradient of decreasing time since burn (Fig. 2B).

Morphospecies diversity, total invertebrate abundance, and abundance of Araneae, Diptera, Hemiptera, Homoptera, Hymenoptera, Lepidoptera, and Orthoptera did not differ between patch-burn and traditional pastures $(P>0.07)$. Only

Table 3. Summary of correlations $\left(r^{2}\right)$ of vegetation characteristics with each dimension of nonmetric multidimensional scaling (NMDS) space and their associated $P$ values. Variables marked with an asterisk are significant at $P<0.05$.

\begin{tabular}{lrrrl}
\hline & NMDS1 & NMDS2 & $r^{2}$ & $P$ value \\
\hline Visual obstruction & -0.21 & 0.98 & 0.04 & 0.55 \\
Bare ground & 0.71 & -0.70 & 0.28 & $0.01^{*}$ \\
Litter & -0.66 & 0.75 & 0.24 & $0.01^{*}$ \\
Live vegetation & -1.00 & 0.04 & 0.13 & 0.10 \\
Dead vegetation & -0.71 & 0.71 & 0.16 & 0.07 \\
Grass & -0.92 & 0.38 & 0.24 & $0.02^{*}$ \\
Forb & -1.00 & -0.03 & 0.01 & 0.90 \\
Shrub & -0.51 & 0.86 & 0.23 & $0.02^{*}$ \\
Tree & -0.98 & 0.22 & 0.01 & 0.76 \\
Shrub density & 0.08 & 1.00 & 0.03 & 0.63 \\
Shrub distance & -0.99 & -0.16 & 0.06 & 0.41 \\
Shrub height & -0.43 & 0.90 & 0.23 & $0.02^{*}$ \\
Time since burn & -0.34 & 0.94 & 0.12 & 0.13 \\
\hline
\end{tabular}

one order, Coleoptera, differed between management strategies and was $34 \%$ higher in traditional pastures $(P=0.009)$.

Morphospecies diversity and total invertebrate abundance did not differ among patch-burn and traditional patches $(P>0.1$, Figs. 3A and 3B, respectively). Araneae and Coleoptera abundance were higher in traditional pastures compared to patch-burn patches $(P<0.05)$. In fact, Araneae abundance was more than twice as high in traditional pastures than in currentyear burn, $12-24$ mo postburn, and $>36$ mo postburn patches (Fig. 4A), and Coleoptera abundance was nearly $3 \times$ higher in traditional pastures than in the current-year burn and 12-24 mo postburn patches (Fig. 4B). Abundance in unburned patches was similar to abundance in traditional pastures for Araneae. Coleoptera abundance in traditional pastures was similar to unburned patches and $>36$ mo postburn in patch-burn pastures. Diptera abundance did not differ among patch-burn and traditional pastures $(P>0.3$, Fig. 4C). Hemiptera abundance differed between current-year burn patches and traditional pastures $(P=0.04)$ with nearly twice as many individuals occurring in current-year burn patches than in traditional pastures (Fig. 4D). Homoptera, Hymenoptera, Lepidoptera, and Orthoptera abundance appeared to not be affected by pyric herbivory, as their abundances were similar in patch-burn and traditional pastures $(P>0.1$, Figs. 4E-4H).

\section{DISCUSSION}

Although numerous authors have investigated the effects of fire or grazing on invertebrate communities, these studies have unnaturally decoupled these processes (Fuhlendorf et al. 2009). This research documents that heterogeneity-based management based on the synergistic relationship between fire and grazing can maintain invertebrate communities in sagebrush mixedgrass prairies. Spatial and temporal heterogeneity generated by pyric herbivory created a mixture of habitat conditions that positively influenced Hemiptera abundance and produced similar abundances to traditional management for seven other invertebrate characteristics, suggesting a heterogeneity-based 

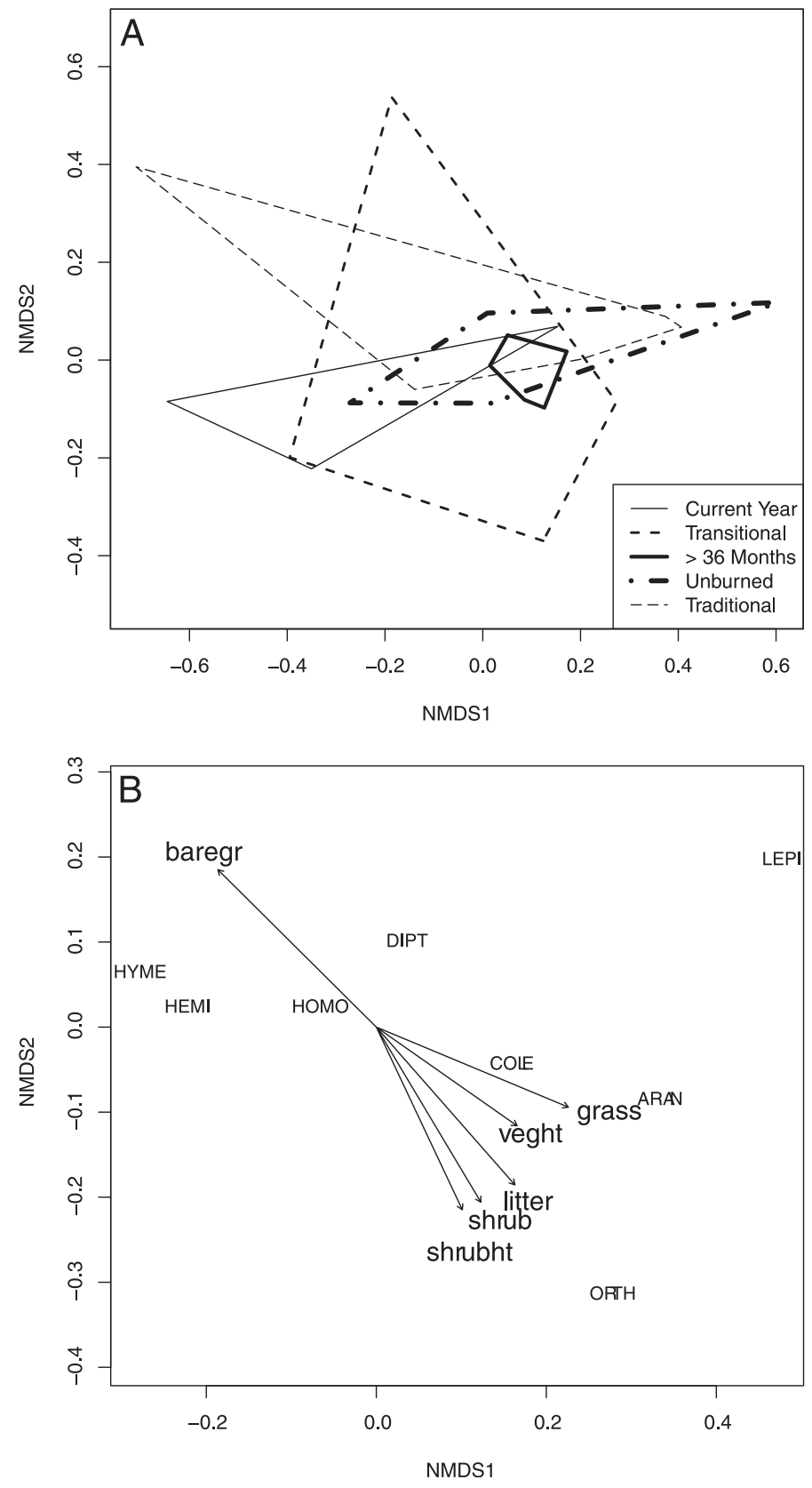

Figure 2. Nonmetric multidimensional scaling (NMDS) ordination plots for eight invertebrate orders examined on Cooper Wildlife Management Area near Woodward, Oklahoma, 2006-2008. A, Polygons representing treatments overlay site scores. B, Correlations between species patterns and habitat variables significant at $P<0.05$ are shown. Abbreviations are as follows: ARAN: Araneae, COLE: Coleoptera, DIPT: Diptera, HEMI: Hemiptera, HOMO: Homoptera, HYME: Hymenoptera, LEPI: Lepidoptera, ORTH: Orthoptera, shrubht: shrub height, shrub: shrub cover, veght: vegetation height, grass: grass cover, and baregr: bare ground.

management scheme does not negatively impact sandsage prairie invertebrate communities. Moreover, heterogeneitybased management may potentially benefit a wider variety of invertebrates by providing areas of varying levels of disturbance (Moranz 2010; Winter 2010). With the availability of vegetation structure (e.g., sandsage stumps) after a fire, vegetation structure may provide habitat that is important for
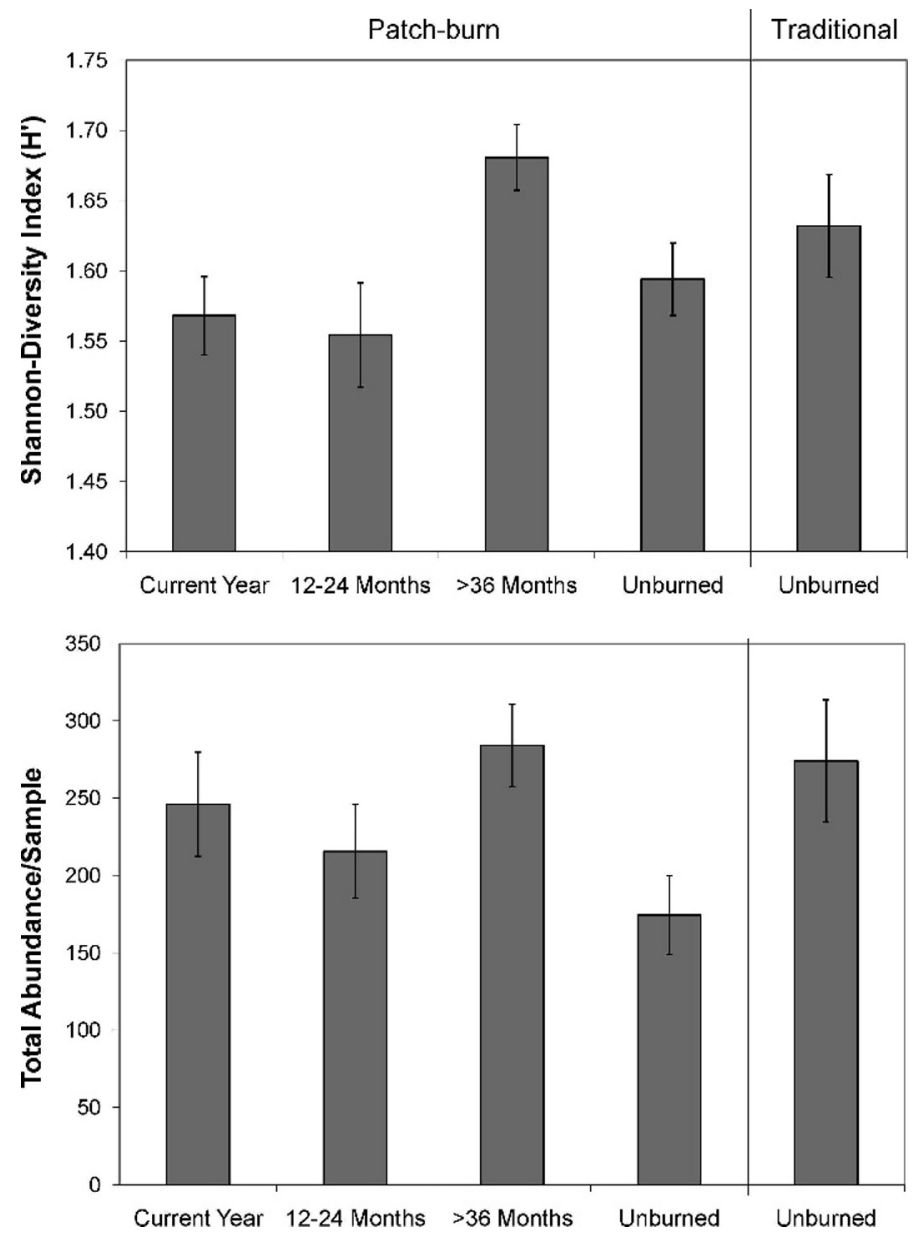

Figure 3. Invertebrate diversity and total invertebrate count by time since burn on Cooper Wildlife Management Area near Woodward, Oklahoma, 2006-2008. Error bars represent \pm 1 standard error. Asterisks represent means that differ from the traditional patches $(P<0.05)$.

the recolonization or recovery of certain invertebrate groups. Although this study was conducted on one wildlife management area, the large size of treatments $(>600 \mathrm{ha})$ is a much better representation of ecological interactions that previous studies using much smaller (i.e., 4-40 ha) plots (Vermeire et al. 2001; Engle et al. 2008; O’Neill et al. 2010).

Many studies have decoupled the effects of fire and grazing, but research has shown the two processes, when combined, have a synergistic relationship (Joern 2005; Jonas and Joern 2007; Engle et al. 2008; Fuhlendorf et al. 2009). Prescribed fire combined with focal grazing impacts the vegetation and invertebrate community on numerous levels, and these impacts vary through time as the amount and level of disturbance shift (Engle et al. 2008; Fuhlendorf et al. 2009). Unlike many experimental designs that decouple fire and grazing, recovery or transitional patches are unique to heterogeneity-based management schemes, as is the matrix of various stages of time since burn and grazing intensity (Fuhlendorf and Engle 2001; Fuhlendorf et al. 2009). The promotion of habitat diversity may benefit a wide variety of organisms. Studies have suggested transitional patches and the creation of varying intensities of disturbance can benefit important grassland 

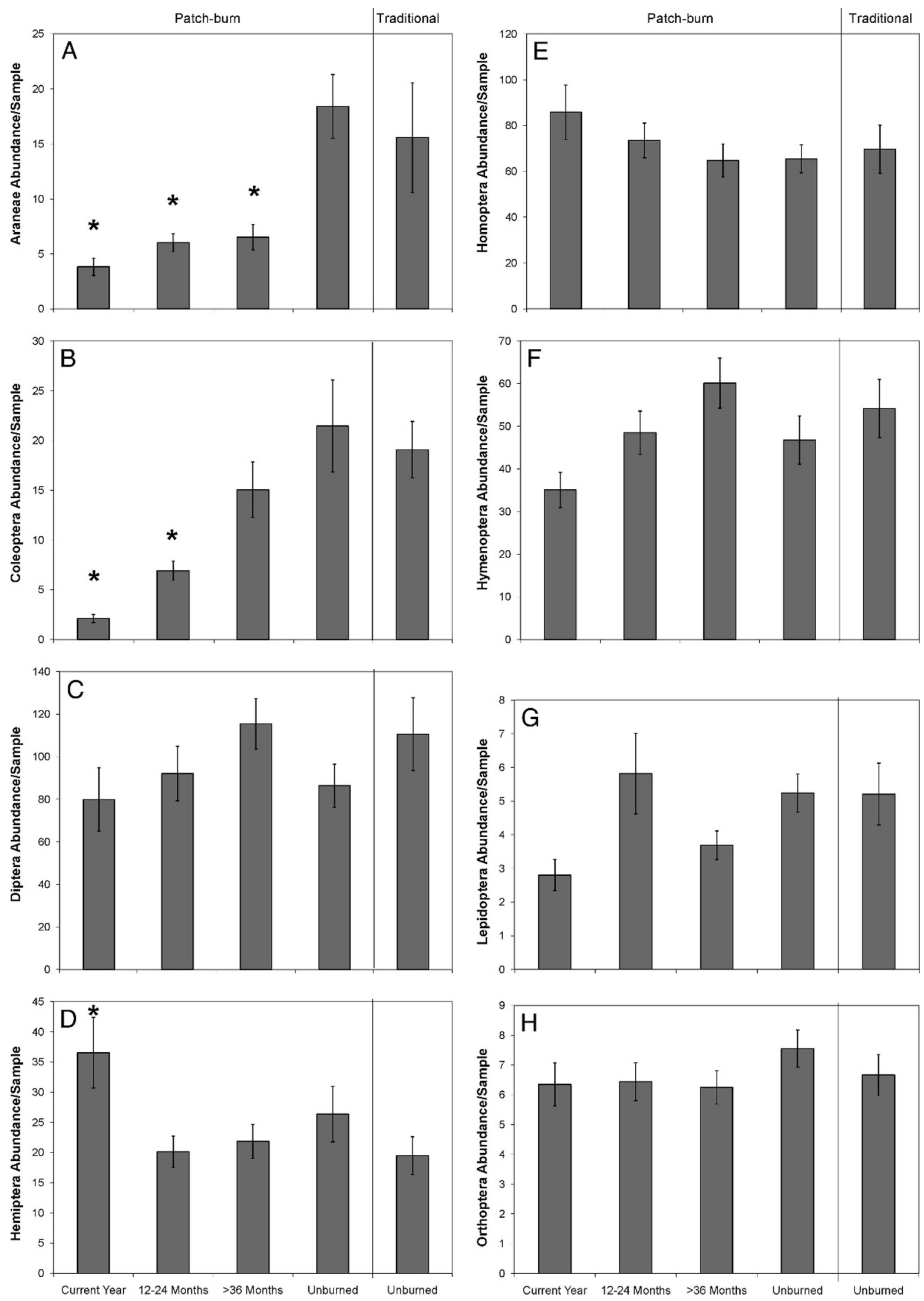

Figure 4. Invertebrate abundance on Cooper Wildlife Management Area near Woodward, Oklahoma, 2006-2008, by time since burn: A, Araneae. B, Coleoptera. C, Diptera. D, Hemiptera. E, Homoptera. F, Hymenoptera. G, Lepidoptera. H, Orthoptera. Error bars represent \pm 1 standard error. Asterisks represent means that differ from the traditional patches $(P<0.05)$. 
invertebrate communities (Joern 2005; Jonas and Joern 2007; Engle et al. 2008).

In our study, two (Araneae and Coleoptera) of the eight taxa responded positively to the traditional management of grazing only. This suggests there are potential conservation implications for widespread adoption of fire-driven grazing on these taxa. Frequency of fire in sandsage ecosystems is poorly understood (Vermeire et al. 2001), and the responses of Coleoptera and Araneae suggest that these taxa may require a longer recovery time in sandsage prairie compared to tallgrass prairie. For instance, many of the species of Araneae collected were orb spiders (Araneidae) that require a substrate for their web spinning. However, work with other similarly impacted invertebrate taxa (i.e., Collembola) suggests that the maintenance of unburned refugia and sufficient fire intervals can mitigate some of the potential negative effects of fire on disturbance-sensitive invertebrate taxa (Harper et al. 2000).

Structural differences in vegetation may help explain some of the major differences we documented between our study and studies conducted in tallgrass prairie. Vegetation differences will have influences on the composition of invertebrate communities and may be important in explaining the response of the community to management. The effects of fire on sand sagebrush ecosystems have been minimally studied (Vermeire et al. 2001), but sandsage resprouted within weeks of a prescribed fire (Winter 2010), potentially creating refugia by which invertebrates may recolonize recently disturbed areas. Vegetation structure also is important because it provides shady, cool microhabitats required by Araneae, Acrididae, and others for refugia (Harper et al. 2000). Comparing our study to other grassland invertebrate studies (e.g., Jonas et al. 2002; Engle et al. 2008), the main vegetational difference is presence of sand sagebrush. In a southwestern Kansas study, Jamison et al. (2002) determined sand sagebrush cover was an important characteristic in explaining biomass of about $40 \%$ of the invertebrates examined. Because of the presence of this structural characteristic, comparisons between these other grassland studies may be inappropriate, but may explain why several invertebrate characteristics were similar between patch-burn and traditional treatments.

In many cases, the spatial configuration of a study area may be just as important to a study organism as habitat quality or availability (Stoner and Joern 2004; Vanbergen et al. 2005; Wood et al. 2006) because different ecological processes work at different spatiotemporal scales (O’Neill et al. 1986). Size of plots and distances among plots can confound the invertebrate response to management. Small plots may not reflect a management response, but may instead relate more to invertebrate vegetation preferences, as the spatial scale can be too small to determine invertebrate responses appropriately (Swengel 2001). As a result of the large patch sizes and distance between sampling points, the results of our study may have better represented the actual response to fire and the subsequent habitat response for at least some species compared to Engle et al. (2008).

Furthermore, patch sizes may have an effect on relative rates of recolonization (Uys et al. 2006). If burned patches are closer in proximity to refugia as would be the case with small patches, the likelihood of recolonization will be higher. Uys et al. (2006) determined $280 \mathrm{~m}$ was the maximum distance from the edge of a burn to permit sufficient recolonization. In our case, this suggests that our burn patches may have been too large to permit adequate recolonization from refugia. When coupled with the xeric microclimates on our site, invertebrates may be further impacted by lowered immigration and decreased vegetation cover, resulting in higher mortality from predation and exposure (Warren et al. 1987), especially because small invertebrates are sensitive to fragmentation and isolation (Burke and Goulet 1998). Although invertebrate mobility studies are limited, Joern $(1982,1983)$ determined Acrididae movement rates ranged from 4.9 to $8.1 \mathrm{~m} / \mathrm{d}$. Thus, it appears dispersal from unburned patches to burned areas may be relatively slow. This may help explain why Coleoptera and Araneae were more abundant in traditional patches. Vagility in these orders may be limited, so it would take longer for these particular taxa to recolonize larger patches.

\section{MANAGEMENT IMPLICATIONS}

Sand sagebrush grasslands and other semiarid habitats are less productive than other grasslands because of decreased rainfall and other vegetation, soil, and climate differences (Gillen and Sims 2004). Several studies examining fire and grazing effects separately have shown decreases in diversity, biomass, and other characteristics of invertebrate communities, possibly due to the simplifying effects of these processes on the plant community (Southwood et al. 1979; Rambo and Faeth 1999; Cagnolo et al. 2002). The habitat heterogeneity hypothesis (Hart and Horwitz 1991) predicts invertebrate diversity and species richness will increase as the diversity of plants and available niches increases. This hypothesis has been supported in a variety of habitats for a variety of invertebrates (Dennis et al. 1998; Engle et al. 2008). Compared to the traditional homogeneous range management, activities that increase spatial variability should be more compatible with the conservation of invertebrate species richness and diversity. Long-term studies examining fire and grazing demonstrate that these processes are important in maintaining invertebrate community diversity and richness (Joern 2005; Jonas and Joern 2007).

Although we do not have any evidence that prescribed fire is extirpating certain invertebrate orders, as suggested by some researchers (Swengel 2001; Summerville 2008), it is important to maintain unburned refuges or less recently burned patches for sources of recolonization (Harper et al. 2000; Panzer 2002). As fire frequency will influence habitat use, it is important to understand how fire frequency varies among grassland systems. Although the fire-return intervals for these habitats are less studied than in tallgrass systems, it is believed this area had a historical fire frequency of 5-10 yr (Wright and Bailey 1982), although others suggest it may be as long as $35 \mathrm{yr}$ (Paysen et al. 2000). Future research should be directed toward determining the fire frequency that is mutually beneficial to a wider spectrum of grassland invertebrate taxa and how the spatial configurations of burned and grazed patches influence invertebrate composition in this understudied ecosystem.

\section{ACKNOWLEDGMENTS}

We wish to thank Alaina Thomas, Jennifer Bryant, Savannah Smith, Colin Walden, Kevin Spears, Kent Andersson, James Richards, and Kenny 
Robertson for assistance with invertebrate collection and sorting. This study was funded by an Oklahoma Department of Wildlife Conservation State Wildlife Grant that was administered through the Oklahoma Cooperative Fish and Wildlife Research Unit. We also wish to acknowledge Department of Natural Resource Ecology and Management and Oklahoma Cooperative Fish and Wildlife Research Unit for research and teaching assistantships. We acknowledge Matthew Lovern, Anthony Joern, David M. Leslie, Jr., and two anonymous reviews for comments on earlier drafts of the manuscript.

\section{LITERATURE CITED}

Anderson, R. C., T. Leahy, and S. S. Dhillion. 1989. Numbers and biomass of selected insect groups on burned and unburned sand prairie. American Midland Naturalist 122:151-162.

Bock, C. E., J. H. Bock, and M. C. Grant. 1992. Effects of bird predation on grasshopper densities in an Arizona grassland. Ecology 73:1706-1717.

Burger, L. W., JR., E. W. Kurzejeski, T. V. Dailey, and M. R. Ryan. 1993. Relative invertebrate abundance and biomass in Conservation Reserve Program plantings in northern Missouri. In: K. E. Church and T. V. Dailey [EDS.]. Quail III: National quail symposium. Pratt, KS, USA: Kansas Department of Wildlife and Parks. p. 102-108.

BuRKE, D., AND H. Goulet. 1998. Landscape and area effects on beetle assemblages in Ontario. Ecography 21:472-479.

Cagnolo, L., S. I. Molina, and G. R. Valladares. 2002. Diversity and guild structure of insect assemblages under grazing and exclusion regimes in a montane grassland from central Argentina. Biodiversity and Conservation 11:407-420.

CRIST, T. 0. 2008. Insect populations, community interactions, and ecosystem process in the shortgrass steppe. In: W. K. Lauenroth and I. C. Burke [EDS.]. Ecology of the shortgrass steppe: a long-term perspective. New York, NY, USA: Oxford University Press. p. 215-247.

DaubenmiRE, R. 1959. A canopy-coverage method of vegetational analysis. Northwest Science 33:43.

Debano, S. J. 2006. Effects of livestock grazing on aboveground insect communities in semi-arid grasslands of southeastern Arizona. Biodiversity and Conservation 15:2547-2564.

Dennis, P., M. R. Young, and I. J. Gordon. 1998. Distribution and abundance of small insects and arachnids in relation to structural heterogeneity of grazed, indigenous grasslands. Ecological Entomology 23:253-264.

Derraik, J. G. B., G. P. Closs, K. J. M. Dickinson, P. Sirvid, B. I. P. Barratt, and B. H. PAтRICK. 2002. Arthropod morphospecies versus taxonomic species: a case study with Araneae, Coleoptera, and Lepidoptera. Conservation Biology 16:1015-1023.

Dietrick, E. J., E. I. Schlinger, and M. J. Garber. 1960. Vacuum cleaner principle applied in sampling insect populations in alfalfa fields by new machine method. California Agriculture 14:9-11.

Dowdy, S., S. Wearden, And D. Chilko. 2004. Statistics for research. Hoboken, NJ, USA: John Wiley and Sons. $640 \mathrm{p}$.

Doxon, E. D., C. A. Davis, and S. D. Fuhlendorf. 2011. Comparison of two methods for sampling invertebrates: vacuum and sweep-net sampling. Journal of Field Ornithology 82:60-67.

Engle, D. M., S. D. Fuhlendorf, A. Roper, and D. M. Leslie Jr. 2008. Invertebrate community response to a shifting mosaic of habitat. Rangeland Ecology \& Management 61:55-62.

Faith, D. P., P. R. Minchin, and L. Belbin. 1987. Compositional dissimilarity as a robust measure of ecological distance. Vegetatio 69:57-68.

Funlendorf, S. D., AND D. M. Engle. 2001. Restoring heterogeneity on rangelands: ecosystem management based on evolutionary grazing patterns. Bioscience 51:625-632

Fuhlendorf, S. D., And D. M. Engle. 2004. Application of the fire-grazing interaction to restore a shifting mosaic on tallgrass prairie. Journal of Applied Ecology 41:604-614.

Fuhlendorf, S. D., D. M. Engle, J. Kerby, and R. Hamilton. 2009. Pyric herbivory: rewilding landscapes through the recoupling of fire and grazing. Conservation Biology 23:588-598.
Gillen, R. L., And P. L. Sims. 2002. Stocking rate and cow-calf production on sand sagebrush rangeland. Journal of Range Management 55:542-550.

Gillen, R. L., AND P. L. Sims. 2004. Stocking rate, precipitation, and herbage production on sand sagebrush-grassland. Journal of Range Management $57: 148-152$

Harper, M. G., C. H. Dietrich, R. L. Larimore, and P. A. Tessene. 2000. Effects of prescribed fire on prairie arthropods: an enclosure study. Natural Areas Journal 20:325-335.

HaRT, D. D., and R. J. Horwitz. 1991. Habitat diversity and the speciesarea relationship: alternative models and tests. In: S. S. Bell, E. D. McCoy, and H. R. Mushinsky [EDS.]. Habitat structure: the physical arrangement of objects in space. London, United Kingdom: Chapman and Hall. p. 47-68.

Hartley, M. K., W. E. Rogers, E. Siemann, and J. Grace. 2007. Responses of prairie arthropod communities to fire and fertilizer: balancing plant and arthropod conservation. American Midland Naturalist 157:92-105

Holecheck, J. L., R. D. Peiper, and C. H. Herbel. 2004. Range management principles and practices. 5th ed. Upper Saddle River, NJ, USA: PearsonPrentice Hall. $624 p$

Jackson, J. R., G. A. Hurst, and E. A. Gluesing. 1987. Abundance and selection of invertebrates by Northern bobwhite chicks. Proceedings of the Annual Conference of the Southeastern Association of Fish and Wildlife Agencies 41:303-310

Jamison, B. E., R. J. Robel, J. S. Pontius, and R. D. Applegate. 2002. Invertebrate biomass: associations with lesser prairie-chicken habitat use and sand sagebrush density in southwestern Kansas. Wildlife Society Bulletin 30:517-526

JoERN, A. 1982. Vegetation structure and microhabitat selection in grasshoppers (Orthoptera, Acrididae). Southwestern Naturalist 27:197-209.

Joern, A. 1983. Small-scale displacements of grasshoppers (Orthoptera: Acrididae) within arid grasslands. Journal of the Kansas Entomological Society 56:131-139.

JoERn, A. 2004. Variation in grasshopper (Acrididae) densities in response to fire frequency and bison grazing in tallgrass prairie. Environmental Entomology 33:1617-1625.

JoERN, A. 2005. Disturbance by fire frequency and bison grazing modulate grasshopper assemblages in tallgrass prairie. Ecology 86:861-873.

JonAS, J. L., AND A. JoERn. 2007. Grasshopper (Orthoptera: Acrididae) communities respond to fire, bison grazing and weather in North American tallgrass prairie: a long-term study. Oecologia 153:699-711.

Jonas, J. L., M. R. Whiles, and R. E. Charlton. 2002. Aboveground invertebrate responses to land management differences in a central Kansas grassland. Environmental Entomology 31:1142-1152.

KreBS, C. 1998. Ecological methodology. 2nd ed. New York, NY, USA: Harper Collins. $624 \mathrm{p}$

KRUSKAL, J. B. 1964. Multidimensional scaling by optimizing goodness of fit to a nonmetric hypothesis. Psychometrika 29:1-27.

Lauenroth, W. K., and I. C. Burke [eds.]. 2008. Ecology of the shortgrass steppe: a long-term perspective. New York, NY, USA: Oxford University Press. $536 \mathrm{p}$.

MARSHALL, S. A. 2006. Insects: their natural history and diversity. Buffalo, NY, USA: Firefly.

Minchin, P. R. 1987. An evaluation of the relative robustness of techniques for ecological ordination. Vegetatio 69:89-107.

Moranz, R. A. 2010. The effects of ecological management on tallgrass prairie butterflies and their nectar sources [dissertation]. Stillwater, OK, USA: Oklahoma State University. $115 \mathrm{p}$.

Morris, M. G., R. T. Clarke, and W. E. Rispin. 2005. The success of a rotational grazing system in conserving the diversity of chalk grassland Auchenorrhyncha. Journal of Insect Conservation 9:363-374.

Nance, E. C., C. A. Steers, E. L. Cole, M. L. Miller, and C. F. Fanning. 1960. Soil survey Woodward County, Oklahoma. Washington, DC, USA: US Department of Agriculture. $113 p$.

National Oceanic and Atmospheric Administration. 2008. 1971-2000 average monthly data for precipitation, snowfall, and temperature for Fort Supply, Oklahoma. 
Available at: http://www.srh.noaa.gov/oun/climate/getnorm.php?id=fsyo2. Accessed 31 October 2008.

Oliver, I., ANd A. J. BeAtTIE. 1996. Designing a cost-effective invertebrate survey: a test of methods for rapid assessment of biodiversity. Ecological Applications 6:594-607.

O'Neill, K. M., S. Blodgett, B. E. Olson, and R. S. Miller. 2008. Impact of livestock grazing on abundance of Miridae and Reduviidae (Hemiptera) in crested wheatgrass pastures. Journal of Economic Entomology 101:309-313.

O'Neill, K. M., B. E. Olson, M. G. Rolston, R. Wallander, D. P. Larson, and C. E. SelBert. 2003. Effects of livestock grazing on rangeland grasshopper (Orthoptera: Acrididae) abundance. Agriculture, Ecosystems \& Environment 97:51-64.

O'Neill, K. M., B. E. Olson, R. Wallander, M. G. Rolston, and C. E. Seibert. 2010. Effects of livestock grazing on grasshopper abundance on a native rangeland in Montana. Environmental Entomology 39:775-786.

O'Neill, R. V., D. L. DeAngelis, J. B. Waide, and T. F. H. Allen. 1986. A hierarchical concept of ecosystems. Princeton, NJ, USA: Princeton University Press. 253 p.

Panzer, R. J. 2002. Compatibility of prescribed burning with the conservation of insects in small, isolated prairie reserves. Conservation Biology 16:1296-1307.

Panzer, R. J., and M. Schwartz. 2000. Effects of management burning on prairie insect species richness within a system of small, highly fragmented reserves. Biological Conservation 96:363-369.

Paysen, T. E., R. J. Ansley, J. K. Brown, G. J. Gottfried, S. M. Haase, M. G. Harrington, M. C. Narog, S. S. Sackett, and R. C. Wilson. 2000. Fire in western shrubland, woodland, and grassland ecosystems. In: J. K. Brown and J. K. Smith [EDS.]. Wildland fire in ecosystems: effects of fire on flora. Fort Collins, CO, USA: US Department of Agriculture, Rocky Mountain Forest and Range Experiment Station, RMRS-GTR-42. p. 121-159.

R Development Core Team. 2010. R: a language and environment for statistical computing, reference index version 2.11.1. Vienna, Austria: R Foundation for Statistical Computing, Available at: http://www.R-project.org. Accessed 16 June 2010.

Ramaley, F. 1939. Sand-hill vegetation of northeastern Colorado. Ecological Monographs 9:1-51.

Rambo, J. L., AND S. H. FAeTH. 1999. Effect of vertebrate grazing on plant and insect community structure. Conservation Biology 13:1047-1054.

ReED, C. C. 1997. Responses of prairie insects and other arthropods to prescription burns. Natural Areas Journal 17:380-385.

Robel, R. J., J. N. Briggs, A. D. Dayton, and L. C. Hilbert. 1970. Relationships between visual obstruction measurements and weight of grassland vegetation. Journal of Range Management 23:295-297.

SAS InStITUte. 2003. SAS/STAT user's guide. Version 9.1.3. Cary, NC, USA: SAS. $5180 \mathrm{p}$.

Schuler, K. L., D. M. Leslie, J. H. Shaw, and E. J. Maichak. 2006. Temporal-spatial distribution of American bison (Bison bison) in a tallgrass prairie fire mosaic. Journal of Mammalogy 87:539-544.
Southwood, T. R. E., V. K. Brown, and P. M. Reader. 1979. Relationships of plant and insect diversities in succession. Biological Journal of the Linnean Society 12:327-348.

Stoner, K. J. L., And A. Joern. 2004. Landscape vs. local habitat scale influences to insect communities from tallgrass prairie remnants. Ecological Applications 14:1306-1320.

SummerVILLE, K. S. 2008. Species diversity and persistence in restored and remnant tallgrass prairies of North America: a function of species' life history, habitat type, or sampling bias? Journal of Animal Ecology 77:487-494.

SwENGEL, A. B. 2001. A literature review of insect responses to fire compared to other conservation managements of open habitat. Biodiversity and Conservation 10:1141-1169.

TOOKER, J. F., AND L. M. HANKs. 2004. Impact of prescribed burning on endophytic insect communities of prairie perennials (Asteraceae: Silphium spp.). Biodiversity and Conservation 13:1875-1888.

Uys, C., M. Hamer, and R. Slotow. 2006. Effect of burn area on invertebrate recolonization in grasslands in the Drakensberg, South Africa. African Zoology 41:51-65.

Vanbergen, A. J., B. A. Woodcock, A. D. Watt, and J. Niemela. 2005. Effect of landuse heterogeneity on carabid communities at the landscape scale. Ecography 28:3-16.

Vermeire, L. T., R. B. Mitchell, and S. D. Fuhlendorf. 2001. Sand sagebrush response to fall and spring prescribed burns. In: E. D. McArthur and D. J. Fairbanks [EDS.]. Proceedings of shrubland ecosystem genetics and biodiversity. Provo, UT, USA: US Department of Agriculture, Forest Service, Rocky Mountain Research Station, RMRS-P-21. p. 233-235.

Vermeire, L. T., R. B. Mitchell, S. D. Fuhlendorf, and R. L. Gillen. 2004a. Patch burning effects on grazing distribution. Journal of Range Management 57:248-252.

Vermeire, L. T., R. B. Mitchell, S. D. Fuhlendorf, and D. B. Wester. 2004b. Selective control of rangeland grasshoppers with prescribed fire. Journal of Range Management 57:29-33.

Warren, S. D., C. J. Scifres, and P. D. Teel. 1987. Response of grassland arthropods to burning: a review. Agriculture Ecosystems \& Environment 19:105-130.

Winter, S. L. 2010. The interaction of fire and grazing in Oklahoma Artemisia filifolia shrubland [dissertation]. Stillwater, OK, USA: Oklahoma State University. $105 \mathrm{p}$.

Wood, P. B., S. B. Bosworth, and R. Dettmers. 2006. Cerulean warbler abundance and occurrence relative to large-scale edge and habitat characteristics. Condor 108:154-165.

Wright, H. A., And A. W. Balley. 1982. Fire ecology: United States and southern Canada. New York, NY, USA: John Wiley \& Sons. 528 p.

ZAR, J. H. 2009. Biostatistical analysis. 5th ed. Upper Saddle River, NJ, USA: Prentice Hall. 960 p. 